\title{
Voorstel voor een EU-richtlijn met betrekking tot het gebruik van digitale instrumenten en processen in het kader van het vennootschapsrecht
}

\author{
Prof. mr.dr. M.A. Verbrug $b^{*}$
}

\begin{abstract}
Op 25 april 2018 heeft de Europese Commissie een richtlijnvoorstel met betrekking tot het gebruik van digitale instrumenten en processen in het kader van het vennootschapsrecht, inclusief een regeling voor gediskwalificeerde bestuurders, openbaar gemaakt. In deze bijdrage wordt het voorstel onderzocht, met bijzondere aandacht voor de rol van de notaris.
\end{abstract}

\section{Inleiding}

Op 25 april 2018 heeft de Europese Commissie twee richtlijnvoorstellen openbaar gemaakt. Het gaat om een voorstel voor een richtlijn tot wijziging van Richtlijn 2017/1132 met betrekking tot grensoverschrijdende omzettingen, fusies en splitsingen, en om een voorstel voor een richtlijn tot wijziging van dezelfde richtlijn met betrekking tot het gebruik van digitale instrumenten en processen in het kader van het vennootschapsrecht. ${ }^{1}$ Het eerste voorstel is al eerder in $\mathrm{MvO}$ besproken. ${ }^{2}$ Daaruit bleek dat naast het faciliteren van grensoverschrijdende mobiliteit, inclusief digitale informatieverstrekking daarover, het voorkómen van fraude en misbruik een belangrijke rol speelt in dit initiatief. In deze bijdrage wordt het voorstel met betrekking tot het gebruik van digitale instrumenten en processen onderzocht. Het voorstel voorziet (voor de $\mathrm{BV}$ verplicht) in volledige online oprichting en registratie van kapitaalvennootschappen en bijkantoren en volledige online indiening van documenten en gegevens. Tevens bevat het voorstel een regeling voor (informatie over) gediskwalificeerde bestuurders. Hoewel digitale facilitering van vennootschappen vooropstaat, speelt ook hier het voorkómen van fraude en misbruik een rol. Gezien de grote rol van de notaris

\footnotetext{
Prof. mr. dr. M.A. Verbrugh is hoogleraar ondernemingsrecht aan Erasmus School of Law.

1. $\operatorname{COM}(2018) 241$ final, resp. $\operatorname{COM}(2018) 239$ final. Voor beide voorstellen sloot op 30 juni 2018 de Nederlandse internetconsultatie. Zie voor de reacties op het tweede voorstel https://www.internetconsultatie.nl/ digioprichtingkapitaalvennootschap/reacties.

2. Zie M.A. Verbrugh, Richtlijnvoorstel voor grensoverschrijdende omzettingen, fusies en splitsingen: een (geheel) nieuwe stap in het harmonisatieproces, $\mathrm{MvO} 2018$, afl. 8-9, p. 232-240.
}

in het Nederlandse vennootschapsrecht ${ }^{3}$ is voor Nederland een belangrijke vraag welke gevolgen aanneming van de richtlijn voor notarissen met zich zal (kunnen) brengen.

Hieronder wordt allereerst de achtergrond van het voorstel besproken. Vervolgens wordt in paragraaf 3 ingegaan op online registratie, online indiening van informatie en openbaarmaking. Paragraaf 4 is gewijd an gediskwalificeerde bestuurders, waarna enkele afsluitende opmerkingen volgen in paragraaf 5 .

\section{Achtergrond}

Het richtlijnvoorstel heeft als doel het gebruik van digitale instrumenten en processen in het kader van het vennootschapsrecht te faciliteren en te bevorderen. De ontwikkeling van een digitale eengemaakte markt is een van de tien hoofdprioriteiten van de Commissie. ${ }^{4}$ In dat kader worden in de toelichting bij het richtlijnvoorstel genoemd de strategie van de Commissie voor een digitale eengemaakte markt van

3. Zie hiervoor de reacties op de Nederlandse internetconsultatie van de Gecombineerde Commissie Vennootschapsrecht (GCV), de KNB en Netwerknotarissen. Zie verder D.F.M.M. Zaman, Het ondernemingsrecht als katalysator voor de economie? (oratie Leiden), 2015, nr. 7. Zie voor (de ontwikkeling van) digitalisering in het algemeen in het notariaat M.I.W.E. Hillen-Muns, Digitalisering in het notariaat, WPNR 2018/7201. Zie voor een overzicht van online facilitering in Nederland The Informal Company Law Expert Group (ICLEG), Report on digitalisation in company law, maart 2016, p. 73, te raadplegen via https://ec. europa.eu/info/sites/info/files/icleg-report-on-digitalisation-24-march -2016_en.pdf. Zie voor digitalisering van notariële registratieprocessen in Nederland, reactie KNB, p. 12. Zie voor een overzicht van de rol van de notaris in het vennootschapsrecht in de 28 lidstaten Everis, Study on digitalisation of company law, 2017, p. 22.

4. $\operatorname{COM}(2018) 239$ final (hierna: Voorstel), p. 2. 
$2015,{ }^{5}$ het actieplan inzake e-overheid van $2016,{ }^{6}$ de verordening over de digitale toegangspoort en het werkprogramma van de Commissie van 2017.7,8

De Commissie wijst erop dat er in de EU aanzienlijke verschillen bestaan tussen de lidstaten als het gaat om de beschikbaarheid van online instrumenten voor de contacten tussen vennootschappen en de overheid op het gebied van het vennootschapsrecht. Sommige lidstaten bieden zeer geavanceerde en gebruiksvriendelijke e-overheidsdiensten aan waarmee essentiele stappen in de levenscyclus van een vennootschap volledig online kunnen worden afgehandeld. In andere lidstaten ontbreken dergelijke online oplossingen volledig. ${ }^{9}$

Voor Nederland geldt dat volledige online oprichting niet mogelijk is (zie verder par. 3.2 hierna), maar wel snel kan: een BV kan in een dag worden opgericht en ingeschreven bij het handelsregister. ${ }^{10}$ Volgens de Koninklijke Notariële Beroepsorganisatie $(\mathrm{KNB})$ kan een Nederlandse BV in vergelijking met vergelijkbare rechtsvormen in andere lidstaten snel, eenvoudig en goedkoop worden opgericht en ingeschreven. ${ }^{11}$

Het gebrek aan regels voor online registratie, indiening van informatie en bekendmaking of de discrepantie tussen de regels in de lidstaten brengt nodeloze kosten en rompslomp met zich voor ondernemers die een bedrijf willen oprichten, hun activiteiten willen uitbreiden door dochterondernemingen of bijkantoren te registreren, of voor het nakomen van bepaalde verplichtingen gebruik willen maken van online procedures, aldus de toelichting. ${ }^{12} \mathrm{Om}$ de kosten en de administratieve lasten voor de vennootschappen te verminderen moeten de lidstaten tevens het eenmaligheidsbeginsel toepassen in het kader van het vennootschapsrecht. Het eenmaligheidsbeginsel houdt in dat een vennootschap informatie die voor verschillende instanties bestemd is, slechts één keer moet verstrekken in plaats van aan elke instantie afzonderlijk. ${ }^{13}$ De

5. $\operatorname{COM}(2015) 192$ final. Zie ook de verwijzing in Voorstel, p. 6, naar een digitaal Europa, Mededeling van de Commissie aan het Europees Parlement, de Raad, het Europees Economisch en Sociaal Comité en het Comité van de Regio's. De eengemaakte markt verbeteren: meer mogelijkheden voor mensen en ondernemingen (COM(2015)550 final).

6. $\operatorname{COM}(2016) 179$ final. Zie over dit actieplan ook Resolutie van het Europees Parlement van 16 mei 2017 over het EU-actieplan inzake e-overheid 2016-2020 (2016/2273(INI)). Zie voorts de op 6 oktober 2017 tijdens het Estse voorzitterschap ondertekende Verklaring van Tallinn over e-overheid.

7. $\operatorname{COM}(2016) 710$ final.

8. Zie voor een korte bespreking van deze initiatieven en documenten Voorstel, p. 2-3.

9. Voorstel, p. 2. Voor bijkantoren is de situatie vergelijkbaar, Voorstel, p. 3.

10. Reactie GCV, nr. 1.5. Het verkrijgen van een bankrekening duurt vanwege de compliancevoorwaarden waaraan de banken moeten voldoen vele malen langer, aldus de GCV.

11. Reactie KNB, p. 2. Dat online registratieoplossingen dit nog sneller, eenvoudiger en goedkoper (kunnen) maken, is geen gegeven. Onderbouwing hiervoor ontbreekt, aldus de KNB. Zie voor (mogelijkheden van) nieuwe technologie voor fiscale wetgeving Het Financieele Dagblad (FD) 26 november 2018, p. 15.

12. Voorstel, p. 4.

13. Zie bijv. Voorstel, p. 6 en overweging (19) Richtlijnvoorstel. Vgl. de authentieke gegevens van art. 9-14 Hregw 2007, waarover Asser/Maeijer \& Kroeze 2-1*2015/267. besparingen als gevolg van de invoering van de online registratie van vennootschappen worden geraamd op EUR 42 tot 84 miljoen per jaar. ${ }^{14}$ Overigens kan een toenemende digitalisering tevens (tijdelijk) tot ongewenste of niet-voorziene resultaten leiden. Zo lijkt de verplichte digitale aanlevering voor kleine bedrijven van jaarstukken over 2016 in Nederland niet alleen te hebben geleid tot een lager nalevingspercentage van tijdige deponering, maar tevens tot minder vrijwillig verstrekte aanvullende informatie. ${ }^{15}$ Naast het wennen aan deze nieuwe verplichting, wordt de vertraging deels veroorzaakt doordat digitale aanlevering geautomatiseerde en daarmee strengere controle mogelijk maakt. ${ }^{16}$

Als waarborgen tegen fraude en misbruik bij het gebruik van digitale oplossingen wijst de Commissie in de toelichting op het voorstel op verplichte identificatiecontrole, regels inzake gediskwalificeerde bestuurders en de mogelijkheid voor de lidstaten om te eisen dat een persoon of instantie, zoals een notaris of advocaat, bij het proces wordt betrokken. ${ }^{17}$

Het richtlijnvoorstel moet zorgen voor meer gelijke kansen voor vennootschappen in de EU en moet tegelijkertijd de lidstaten de nodige flexibiliteit bieden om hun nationale systemen aan te passen aan hun behoeften en hun juridische tradities te behouden, aldus de Commissie. ${ }^{18}$ Wat dat laatste betreft is niet bij alle onderdelen precies duidelijk welke ruimte lidstaten geacht worden te behouden. ${ }^{19}$ Daarbij geldt tevens dat hoe groter deze ruimte is, des te minder er sprake zal zijn van harmonisatie in de EU. ${ }^{20}$

De Commissie heeft bij de voorbereiding van het voorstel samengewerkt met belanghebbende partijen en breed overleg gevoerd tijdens het effectbeoordelingsproces. Het raadplegingsproces bestond uit een openbare raadpleging, vergaderingen met belanghebbenden, besprekingen met deskundigen van de lidstaten en verschillende studies. ${ }^{21} \mathrm{Bij}$ de online openbare raadpleging 'modernisering van het vennootschapsrecht van de EU: regels voor digitale oplossingen en efficiënte grensoverschrijdende activiteiten', die van 10 mei 2017 tot 6 augustus 2017 liep, waren - in tegenstelling tot de andere groepen vrijwel alle notarissen het oneens met de stelling dat het gebrek aan wetgeving problemen opleverde, en deelden de

14. Commission staff working document impact assessment, SWD(2018)141 final, p. 47 en 86. In de toelichting, Voorstel, p. 8, wordt bij dezelfde besparing naast online registratie de online indiening van informatie genoemd.

15. FD 7 november 2018 , p. 2 . Dat laatste wordt veroorzaakt doordat daarvoor aanvullende software nodig is.

16. FD 7 november 2018 , p. 2 . Tegenover minder tijdig ingediende jaarrekeningen staat dus wel een hogere kwaliteit van de jaarrekeningen, aldus Verkruijsse in het FD.

17. Voorstel, p. 5.

18. Voorstel, p. 6 en overweging (12) Richtlijnvoorstel.

19. Zie wat betreft de rol van de notaris verder par. 3.2.

20. Zie kritisch over de ruimte voor lidstaten in het voorstel, reactie VNONCW en MKB-Nederland, p. 3.

21. Zie Voorstel, p. 9 e.v. Zie o.a. ICLEG 2016; Everis 2017; Optimity Advisors en Tipik Legal, Assessment of the impacts of using digital tools in the context of cross-border company operations, 2017. 


\section{Maandblad}

Ondernemingsrecht

overtuiging dat de EU zich helemaal niet met dit onderwerp moet bezighouden. ${ }^{22}$

Het richtlijnvoorstel is bedoeld ter aanvulling van de bestaande regels inzake het vennootschapsrecht van de EU die zijn gecodificeerd in Richtlijn (EU) 2017/1132. ${ }^{23}$ Bij de bestaande regels moet met name worden gedacht aan de verplichting diverse gegevens over kapitaalvennootschappen en over de bestuurders daarvan openbaar te maken, ${ }^{24}$ en aan informatie over bijkantoren. ${ }^{25}$ Het richtlijnvoorstel bouwt tevens voort op het systeem van gekoppelde ondernemingsregisters van de lidstaten (Business Registers Interconnection System (BRIS)). ${ }^{26}$ Het richtlijnvoorstel is in Nederland van toepassing op de BV en de NV. Voor de NV worden niet alle onderdelen verplicht gesteld. ${ }^{27}$

\section{Online registratie, online indiening van informatie en openbaarmaking}

\subsection{Inleiding}

In titel I (Algemene bepalingen en de oprichting en werking van kapitaalvennootschappen) van Richtlijn 2017/1132 wordt de titel van hoofdstuk III vervangen door 'Online registratie, online indiening van informatie, openbaarmaking en registers' ${ }^{28}$ Evenals in het huidige hoofdstuk III ziet het richtlijnvoorstel wat betreft oprichting en informatie zowel op kapitaalvennootschappen als op bijkantoren. Nieuw is het voorstel voor een regeling over gediskwalificeerde bestuurders.

Nieuw in hoofdstuk III is tevens de verplichting voor lidstaten om online informatie beschikbaar te stellen over de registratie en indiening van informatie en, wat betreft de in bijlage IIA genoemde vennootschapsvormen (in Nederland: BV's), zelfs over diverse kernonderwerpen in het vennootschapsrecht. ${ }^{29}$ Het gaat daarbij onder meer om: (d) de bevoegdheden en ver-

22. Voorstel, p. 9-10 en Feedback Statement to the 2017 Public Consultation 'EU Company Law upgraded: digital solutions and providing efficient rules for cross-border operations of companies', p. 3. Zie voor een (sterke) nuancering van dit beeld, reactie Netwerknotarissen, p. 5-6.

23. Voorstel, p. 6. Zie over de openbaarmakingsverplichtingen vanuit EUrecht J.N. Schutte-Veenstra, Europees vennootschapsrecht (Serie Ondernemingsrecht, deel A-15), Den Haag: Sdu Uitgevers 2013, p. 121 e.v.

24. Voorts moet financiële informatie openbaar worden gemaakt. Zie art. 14 en 16 Richtlijn 2017/1132. Deze verplichtingen vinden hun oorsprong in de Eerste richtlijn van 1968. Zie voorts de verplichtingen uit het jaarrekeningenrecht.

25. Zie art. 29 e.v. Richtlijn 2017/1132. Deze verplichting vindt haar oorsprong in de Elfde richtlijn van 1989.

26. Zie voor de wettelijke verplichtingen daartoe Richtlijn 2012/17/EU, art. 22 e.v. en Uitvoeringsverordening (EU) 2015/884. Zie verder ICLEG 2016, par. 5.3.

27. Art. 13 Voorstel verwijst naar bijlage II, I en IIA. II en I zijn bestaande bijlagen bij Richtlijn 2017/1132, bijlage IIA is nieuw bij het voorstel opgenomen. Voor Nederland geldt dat II ziet op de NV en BV, I alleen op de NV en IIA alleen op de BV. In diverse andere lidstaten, zoals Frankrijk en België, geldt een ruimer palet aan kapitaalvennootschappen.

28. De huidige titel luidt: 'Openbaarmaking en koppeling van centrale, handels- en vennootschapsregisters'.

29. Zie art. 13 sexies Voorstel. De lidstaten moeten de informatie verstrekken op de websites die via de bij Verordening (EU) 1024/2012 ingestelde digitale toegangspoort beschikbaar zijn. antwoordelijkheden van het bestuurs-, leidinggevend en toezichthoudend orgaan van de vennootschap of het bijkantoor, inclusief de vertegenwoordiging van de vennootschap of het bijkantoor ten aanzien van derden, (e) de voorwaarden om lid te worden van het bestuurs-, leidinggevend en toezichthoudend orgaan van de vennootschap of het bijkantoor, (f) bijzonderheden over het besluitvormingsproces van het bestuurs-, leidinggevend en toezichthoudend orgaan van de vennootschap of het bijkantoor, (g) bijzonderheden over de rechten en plichten van de aandeelhouders, en (h) gegevens over de betaling van dividenden en andere vormen van uitkeringen. Verwarrend is dat zowel vennootschappen als bijkantoren in (d) en (e) worden genoemd, nu bijkantoren geen organen kennen. Tevens roept de term 'verantwoordelijkheden' naast 'bevoegdheden' in (d) vragen op. Wat onder 'bijzonderheden' bij (f) en (g) moet worden verstaan, is eveneens onduidelijk.

In de toelichting bij het voorstel is te lezen dat personen die grensoverschrijdend vennootschappen en bijkantoren willen oprichten en exploiteren, gemakkelijk toegang moeten hebben tot alle relevante informatie over de registratie van en indiening van informatie over dergelijke ondernemingen. ${ }^{30} \mathrm{Waar}$ om de informatieverplichting ruimer is en tevens ziet op algemeen vennootschapsrechtelijke onderwerpen en waarom alleen voor vennootschappen uit bijlage IIA, wordt niet toegelicht. Zeker nu dit tevens moet geschieden in een officiële taal van de Unie die zo veel mogelijk grensoverschrijdende gebruikers in grote lijnen begrijpen, lijkt zij bedoeld om de oprichting van vennootschappen in andere lidstaten aan te moedigen. Dat gaat verder dan het louter faciliteren van (geplande) oprichtingen en informatievoorziening. In combinatie met het richtlijnvoorstel voor grensoverschrijdende mobiliteit kan goed toegankelijke informatie over buitenlands vennootschapsrecht de concurrentiestrijd om vennootschapsrechtssystemen versterken.

\subsection{Online registratie van vennootschappen en bijkantoren}

Als kernbepaling in het voorstel geldt dat vennootschappen en bijkantoren volledig online kunnen worden geregistreerd (opgericht) ${ }^{31}$ zonder dat de aanvragers of hun vertegenwoordigers zich daarvoor fysiek moeten aanmelden bij een bevoegde autoriteit of een andere persoon of instantie die de registra-

30. Voorstel, p. 14.

31. In het voorstel wordt met registratie de oprichting van een vennootschap bedoeld, zie art. 13 bis sub 3 Voorstel. In Nederland vallen beide niet samen, nu de oprichting plaatsvindt bij notariële akte (art. 2:64/175 lid 2 $\mathrm{BW}$ ), waarna registratie (inschrijving) in het handelsregister plaatsvindt. De bestuurders zijn tot inschrijving verplicht (art. 2:69/180 BW), maar in de praktijk zorgt de notaris daarvoor. Dat gebeurt veelal digitaal via Online registreren Handelsregister voor notariskantoren, een service van de Kamer van Koophandel, aldus de KNB, reactie, p. 5. 
tieaanvraag behandelt. ${ }^{32}$ De lidstaten kunnen evenwel besluiten om voor NV's niet te voorzien in registratieprocedures die volledig online kunnen worden afgewikkeld. ${ }^{33} \mathrm{Als}$ reden voor deze uitzondering geldt de complexiteit van de oprichting en de registratie van dergelijke ondernemingen. ${ }^{34}$ Omdat bij de oprichting van NV's meestal complexe vraagstukken een rol spelen, variërend van kapitaalstorting tot bijzondere statutaire regelingen, is de Gecombineerde Commissie Vennootschapsrecht (GCV) van mening dat de Nederlandse regering voor de $\mathrm{NV}$ van deze uitzondering gebruik moet maken. ${ }^{35} \mathrm{Nu}$ (de oprichting van) het aantal NV's aanzienlijk lager ligt dan het aantal BV's, is de impact van een uitzondering in Nederland relatief beperkt. Maar omdat de inhoudelijke rol van de notaris niet lijkt te zijn uitgespeeld in het richtlijnvoorstel (zie hierna) en ook zonder een fysiek samenkomen kan worden vervuld, is de vraag of een uitzondering gezien het complexe karakter bij de NV nodig is. Onduidelijk is of de uitzonderingsmogelijkheid ook geldt voor bijkantoren van NV's, aldus de GCV. ${ }^{36}$ Hoewel de toelichting de regeling voor online registratie van bijkantoren beschouwt als analoog aan de online registratie van vennootschappen, ${ }^{37}$ hetgeen een uitzondering voor bijkantoren van NV's impliceert, wijst het niet opnemen van de uitzondering in de regeling voor bijkantoren op de mogelijkheid van online registratie in alle gevallen. $\mathrm{Nu}$ bovendien de registratie van een bijkantoor van een NV niet complexer is dan van een $\mathrm{BV}$, kan mijns inziens worden geconcludeerd dat geen uitzondering is bedoeld in het voorstel.

Het richtlijnvoorstel voorziet in een belangrijke uitzondering op de verplichte mogelijkheid van online registratie zonder fysieke aanmelding bij een bevoegde instantie. Voor de online registratie (en voor de online indiening van informatie) voorziet artikel 13 ter Richtlijnvoorstel in een regeling van erkenning van identificatiemiddelen. ${ }^{38}$ Onverminderd de identificatiemiddelen die in de lidstaten moeten kunnen worden gebruikt, kunnen lidstaten maatregelen treffen op grond waarvan de betrokken persoon in geval van een oprecht, op redelijke gronden gebaseerd vermoeden van fraude zich fysiek moet aanmelden bij de voor de online registratie of de online indiening van informatie bevoegde autoriteit om zijn identiteit te

32. De KNB, reactie, p. 7, vraagt zich af of de voorgestelde regeling voor online oprichting in plaats van of naast de bestaande regeling komt. Gezien de bewoordingen in art. 13 septies Voorstel en in de toelichting, p. 14 , gaat het om de mogelijkheid tot online oprichting en staat het lidstaten m.i. dus vrij de regeling naast de bestaande regeling in te voeren.

33. Zie art. 13 septies (vennootschappen) en art. 28 bis (bijkantoren) Voorstel. In de evaluatie van de richtlijn, die vijf jaar na aanneming ervan moet worden uitgevoerd, komt de vraag aan de orde of het noodzakelijk en haalbaar is te voorzien in de volledige online registratie van NV's. Zie art. 3 Voorstel.

34. Voorstel, p. 14.

35. Reactie GCV, nr. 2.4.

36. Reactie GCV, nr. 2.11

37. Voorstel, p. 16.

38. Het gaat om de identificatiemiddelen die aan de zogenaamde eIDAS-vereisten voldoen, maar lidstaten mogen ook andere middelen erkennen. Zie over eIDAS-wetgeving: ICLEG 2016, p. 12; Everis 2017, p. 26 e.v. laten verifiëren. ${ }^{39}$ De toelichting bij het artikel biedt geen verdere houvast wanneer hiervan sprake kan zijn, maar in overweging (14) bij het voorstel worden als voorbeelden van redelijke gronden genoemd informatie uit de registers van uiteindelijke begunstigden of de nationale strafregisters of aanwijzingen voor identiteitsfraude of belastingontduiking. ${ }^{40}$

Het richtlijnvoorstel verplicht de lidstaten tot het vaststellen van voorschriften voor de online registratie van vennootschappen en bijkantoren en specificeert welke elementen daarin verplicht moeten worden vastgelegd. ${ }^{41}$ Voor de registratie van vennootschappen specificeert de regeling tevens welke elementen er facultatief in kunnen worden opgenomen. ${ }^{42}$ De opgesomde elementen en de verdeling tussen verplicht en facultatief roepen diverse vragen op. Zo vraagt de GCV zich af of de procedures over de rechtmatigheid van het doel, de oprichtingsakten en de benoeming van bestuurders niet verplicht moeten worden gesteld, aangezien art. 11 Richtlijn 2017/1132 het ontbreken hiervan als een grond voor nietigheid aanmerkt. ${ }^{43}$

Voor de online registratie van vennootschappen voorziet het voorstel tevens in een regeling inzake modellen voor de registratie. Lidstaten worden verplicht modellen voor de registratie van de in bijlage IIA genoemde vennootschapsvormen (voor Nederland: BV's) beschikbaar te stellen. ${ }^{44}$ Voor vennootschapsvormen die in bijlage II, maar niet in bijlage IIA worden vermeld (in Nederland: NV's), is het gebruik van modellen facultatief. De inhoud van de modellen valt onder nationaal recht. De lidstaten stellen deze modellen ten minste beschikbaar in een officiële taal van de Unie die zo veel mogelijk grensoverschrijdende gebruikers in grote lijnen begrijpen. In

39. Art. 13 septies lid 1 (vennootschappen)/28 bis lid 1 (bijkantoren) jo. art. 13 ter lid 4 Voorstel. Zie voor indiening van informatie art. 13 decies lid 1 jo. art. 13 ter lid 4 Voorstel.

40. In de reacties op de Nederlandse consultatie wordt veel aandacht gevraagd voor het risico op fraude bij de online facilitering. De reactie van de KNB, p. 4, vermeldt dat het voorstel als voorbeelden identiteitsfraude en belastingontduiking noemt, en is van mening dat de reikwijdte ruimer moet zijn en dient te zien op alle vormen van fraude en misbruik. Duidelijk is dat een ruimer bereik is bedoeld. Niet alleen gaat het (slechts) om voorbeelden en worden er in overweging (14) meer dan twee voorbeelden genoemd, in het artikel en de toelichting (p. 14) wordt van fraude in het algemeen gesproken. Bij de registers van uiteindelijke begunstigden kan aan het UBO-register worden gedacht. Zie over dit register en over het centraal aandeelhoudersregister, reactie KNB, p. 9-10.

41. $\mathrm{Bij}$ de online registratie van bijkantoren kan gebruik worden gemaakt van eerder bij een register ingediende documenten of gegevens (art. 28 bis lid 2 Voorstel). De GCV, reactie nr. 2.12, wijst hierbij op een mogelijk probleem bij het gebruik van een andere (onbekende) taal.

42. Zie art. 13 septies lid 2-4, respectievelijk art. 28 bis Voorstel.

43. Reactie GCV, nr. 2.5. In art. 13 septies lid 3 sub a Voorstel gaat het, naast de handelingsbekwaamheid, om de bevoegdheid van de aanvragers de vennootschap te vertegenwoordigen, terwijl de vennootschap bij oprichting nog niet bestaat. Dat is anders voor de vergelijkbare bepaling in art. 28 bis Voorstel voor bijkantoren, nu de vennootschap in dat geval wel bestaat.

44. Zie art. 13 octies Voorstel. Daarmee is ook de vraag waarom het element 'controle van het correcte gebruik van de modellen' (art. 13 septies lid 4 sub c Voorstel) facultatief is, zeker nu daar in art. 13 octies lid 2 Voorstel naar wordt verwezen. 


\section{Maandblad \\ Ondernemingsrecht}

de praktijk zal het daarbij om een tweede, buitenlandse taal gaan. Grensoverschrijdende gebruikers zullen in de praktijk veelal met name uit een of meer aangrenzende lidstaten afkomstig zijn, en daarmee zal deze tweede taal in de lidstaten vermoedelijk verschillen. Hoewel het opleggen van een specifieke tweede taal gevoelig kan liggen in de lidstaten, is er met de interne markt veel voor te zeggen om hiervoor een gemeenschappelijke taal aan te wijzen. Aannemelijk is dat de meeste grensoverschrijdende gebruikers het Engels in grote lijnen begrijpen. ${ }^{45}$

Er geldt een algemene maximumtermijn van vijf werkdagen waarbinnen de online registratie van vennootschappen of bijkantoren moet worden afgerond. Zoals uit paragraaf 2 bleek, kan een Nederlandse BV op dit moment in een dag worden opgericht en ingeschreven bij het handelsregister.

De evaluatie van de richtlijn, die vijf jaar na aanneming ervan moet worden uitgevoerd, heeft onder meer betrekking op de vraag of het noodzakelijk en haalbaar is om (1) de lidstaten modellen te laten verstrekken voor alle soorten kapitaalvennootschappen, en (2) een geharmoniseerd model te verstrekken dat door alle lidstaten moet worden gebruikt voor de in bijlage IIA (in Nederland: BV's) genoemde vennootschapsvormen. ${ }^{46}$ Dat laatste zou een stap verder gaan dan digitale facilitering, het onderwerp van de richtlijn, nu het daarbij gaat om een inhoudelijke en daarmee nieuwe EU-harmonisatie van oprichtingen.

De online oprichting en het gebruik van modellen doen denken aan het (recent ingetrokken) voorstel voor een eenpersoons-BV (SUP). ${ }^{47}$ Een belangrijk verschil is dat het bij de SUP gaat om een model voor oprichting en statuten, terwijl het hier besproken richtlijnvoorstel alleen ziet op modellen voor oprichting. ${ }^{48}$

45. Een Brexit kan daarbij behulpzaam zijn, omdat het Engels dan als een meer neutrale taal kan worden ervaren. Vanuit Nederland bezien noemt de GCV (reactie, nr. 2.6.), naast het Nederlands, 'wellicht het Engels'. Hetzelfde geldt bij andere onderwerpen waar een taal wordt voorgeschreven die zo veel mogelijk grensoverschrijdende gebruikers in grote lijnen begrijpen.

46. Art. 3 Voorstel.

47. Zie voor de SUP, $\operatorname{COM}(2014) 212$. Een herzien voorstel is aangenomen door de Raad voor Concurrentievermogen op 28 mei 2015. In het Werkprogramma van de Commissie voor 2018 van 24 oktober 2017 (COM(2017)650 final), Annex 4, nr. 10, heeft de Commissie aangekondigd dat het SUP-voorstel zou worden ingetrokken, hetgeen is geschied op 3 juli 2018. Zie voor het (angepaste) voorstel H.E. Boschma, Het plan voor een nieuwe EU-richtlijn voor de eenpersoonsvennootschap. Is de voorgestelde nieuwe rechtsvorm van de SUP een goed idee?, Ondernemingsrecht 2014/144; H.E. Boschma, Het plan voor een nieuwe EUrichtlijn voor de eenpersoonsvennootschap: Raad bereikt algemene oriëntatie, Ondernemingsrecht 2015/107; J.N. Schutte-Veenstra \& H.E. Boschma, Will the SUP be an effective legal form for SMEs as well as for subsidiaries within the European Union?, European Journal of Comparative Law and Governance (4) 2017, afl. 3, p. 246-287 (doi: 10.1163/22134514-00403004).

48. Netwerknotarissen, reactie, p. 6-7, en VNO-NCW en MKB-Nederland, reactie, p. 3, gaan er ten onrechte van uit dat het richtlijnvoorstel voorziet in modelstatuten. Een ander verschil is dat de SUP volgens het richtlijnvoorstel maar één aandeelhouder kent.
De verplichte inschakeling van de notaris, zoals die nu in Nederland in de praktijk wordt ingevuld, staat een volledige online oprichting in de weg. Uit de reacties op de Nederlandse consultatie, die - niet verrassend - met name uit de notariële hoek komen, blijkt dat er zorgen en onduidelijkheden bestaan over de gevolgen van het voorstel voor de toekomstige rol van de notaris. ${ }^{49}$ Die twijfel wordt met name veroorzaakt doordat er bij gebruik van de modellen van uit wordt gegaan dat aan de eis om de oprichtingsakte bij authentieke akte te verlijden, is voldaan. ${ }^{50}$ Zo vraagt de GCV zich af of er daardoor voortaan vennootschappen kunnen worden opgericht met en zonder inzet van een notaris, en stelt Netwerknotarissen de vraag of de notariële tussenkomst bij de oprichting van een BV wordt gewaarborgd.

Mijns inziens is duidelijk dat, indien door de Nederlandse wetgever gewenst, de tussenkomst van de notaris bij alle oprichtingen gehandhaafd kan blijven. Wat betreft de regeling over de authentieke akte geldt dat artikel 13 octies - onder toevoeging van 'in voorkomend geval' - verwijst naar een facultatieve regeling over de modellen. Het staat Nederland dus vrij daarvan geen gebruik te maken. ${ }^{51}$ Voorts kan worden gewezen op de opmerkingen dat (1) het voorstel nationale rechtstradities onverlet laat, met name wat de rol van notarissen bij de registratie van vennootschappen betreft, en dat (2) de lidstaten moeten kunnen eisen dat notarissen of advocaten bij het online registratieproces worden betrokken, mits dat het volledig online afwikkelen van de registratieprocedure niet in de weg staat. ${ }^{52}$ De notaris zal er met andere woorden alleen voor moeten zorgen dat zijn tussenkomst zonder fysieke bijeenkomst kan plaatsvinden. De GCV wijst in haar reactie naar Oostenrijk, waar voor notariële akten wordt geëxperimenteerd met een elektronische oprichting via video conferencing. Deze vorm van elektronische oprichting tast de kwaliteit van de notariële zorgplicht en identificatie niet of nauwelijks aan, terwijl het Europese oprichtingen sterk vergemakkelijkt, aldus de commissie. ${ }^{53}$ De KNB wijst erop dat het notariaat met de introductie van een digitale notariële akte en de inzet van videoconferentie en digitale identificatiemiddelen goed kan voldoen aan volledige online registratie van vennoot-

49. Zie daarnaast D.F.M.M. Zaman, Het spanningsveld binnen het ondernemingsrecht: faciliteren en toch misbruik tegen gaan, WPNR 2018/7212. In de reacties op de consultatie wordt tevens de maatschappelijke rol van de notaris bij oprichtingen benadrukt. Minder bezorgd is de KNB, reactie, p. 3, die verheugd is dat de Commissie het maatschappelijk belang van notariële tussenkomst bij oprichting erkent.

50. Zie art. 13 octies lid 2 Voorstel. Zie voor de eis van authentieke akte art. 10 Richtlijn 2017/1132. Zie reactie GCV, nr. 2.1 en Netwerknotarissen, p. 7. Volgens de KNB, reactie, p. 7, dient de fictie van het hebben voldaan aan de eis van authentieke akte te vervallen.

51. Ook zou de notaris in Nederland bij deze facultatieve regeling in art. 13 septies lid 2 sub c Voorstel kunnen worden aangewezen als de contolerende autoriteit.

52. Zie Voorstel, p. 8 en overweging (12) en (13)

53. Reactie GCV, nr. 1.6. 
schappen met de maatschappelijk relevante notariële waarborgen van fraudepreventie en rechtszekerheid. ${ }^{54}$

Uiteraard is ook mogelijk dat Nederland kiest voor oprichting met en oprichting zonder tussenkomst van de notaris, afhankelijk van de wens van de gebruiker. ${ }^{55}$ In het tweede geval zal de wetgever dan tevens modelstatuten moeten opstellen. Het zal niet verbazen dat vanuit notariële hoek wordt gepleit voor betrokkenheid van de notaris bij alle oprichtingen. ${ }^{56} \mathrm{Het}$ argument van voorlichting daarbij speelt mijns inziens bij 'eenvoudige' vennootschappen een minder grote rol, nu basisinformatie via een website zelf kan worden ingewonnen of door een andere jurist kan worden verstrekt. En de veelgehoorde toekomstvisie van blockchaintechnologie, die de notaris (grotendeels) overbodig makkt, speelt niet zozeer bij oprichtingen. Een sterk(er) argument voor betrokkenheid van de notaris is zijn maatschappelijke rol om fraude en witwassen tegen te gaan. Om die rol goed te kunnen vervullen is persoonlijk contact met de cliënt noodzakelijk, aldus Netwerknotarissen. ${ }^{57}$ In dat licht en gezien de verdere digitalisering die na aanneming van de richtlijn wordt bereikt, zou de Nederlandse wetgever er goed aan doen bij de uitvoering van de richtlijn vast te houden aan tussenkomst van de notaris en kan zijn positie op een later moment opnieuw worden bekeken.

\subsection{Online indiening, openbaarmaking van en toegang tot informatie}

Zoals bekend moeten bij oprichting van kapitaalvennootschappen en bijkantoren diverse documenten en gegevens, alsook wijzigingen daarvan, worden ingediend bij het handelsregister en hebben derden recht om informatie op te vragen. ${ }^{58}$ Hoewel bij deze onderwerpen al eerder stappen zijn gezet door de Europese wetgever om elektronische indiening en opvraging mogelijk te maken, voorziet het richtlijnvoorstel ook hier in een verdergaande online facilitering. Zo geldt in het voorstel niet langer als uitgangspunt bekendmaking in een nationaal publicatieblad en, voor zover lidstaten hieraan willen vasthouden, rust er een verplichting om informatie door te zenden aan het publicatieblad op het register en niet op de vennootschap. Met dit laatste wordt uitvoering gegeven aan

54. Reactie KNB, p. 3. Op dit moment moet een notariële akte nog in papieren vorm worden opgemakt (reactie, p. 13). Zie over een digitale notariele akte verder Hillen-Muns 2018, p. 561. Zie voor de vraag of voorlichting op afstand zou kunnen geschieden, Hillen-Muns 2018, p. 560.

55. Zo is het ontbreken van notarieel of ander toezicht niet bezwaarlijk als de waarborgen tegen fraude en misbruik zijn verzekerd, aldus VNO-NCW en MKB-Nederland, reactie, p. 3.

56. Zie bijv. reactie GCV, nr. 2.1, die stelt dat de notariële tussenkomst digitaal kan geschieden.

57. Zie bijv. reactie Netwerknotarissen, p. 6, die tevens ingaat op de rol van de notaris op grond van de Vierde en het voorstel van de Vijfde antiwitwasrichtlijn. Zie daarvoor ook, reactie KNB, p. 3.

58. Het gaat om art. 14 e.v. (vennootschappen) en art. 29 e.v. (bijkantoren) Richtlijn 2017/1132. Zie voor (de uitvoering in) Nederland, SchutteVeenstra 2013, p. 121 e.v. en Asser/Maeijer \& Kroeze 2-1* 2015/267 e.v. het eenmaligheidsbeginsel. ${ }^{59}$ Voorts geldt onder meer dat de lidstaten ervoor moeten zorgen dat alle documenten en gegevens die aan een bevoegde autoriteit zijn verstrekt in het kader van de online registratie of indiening van informatie over een vennootschap of bijkantoor, door de registers worden opgeslagen in een machineleesbaar en -doorzoekbaar format of als gestructureerde gegevens. ${ }^{60}$

Nieuw is met name het voorstel voor een regeling over het aantal gegevens dat kosteloos moet worden verstrekt. ${ }^{61} \mathrm{De}$ toegang tot deze aanvullende vennootschapsgegevens moet de eengemaakte markt transparanter maken en het vertrouwen in de eengemaakte markt vergroten, aldus de toelichting. ${ }^{62}$ Aan de huidige gegevens die kosteloos moeten worden verstrekt, ${ }^{63}$ wordt toegevoegd: (d) de gegevens over de website van de vennootschap, indien van toepassing, (e) de juridische status van de vennootschap, ${ }^{64}$ (f) het doel van de vennootschap, mits opgenomen in het nationale register, ( $\mathrm{g}$ ) het aantal werknemers van de vennootschap, wanneer deze informatie beschikbaar is in de financiële overzichten van de vennootschap als vereist door het nationale recht, ${ }^{65}(\mathrm{~h})$ de naam van personen die door de vennootschap zijn gemachtigd om haar ten opzichte van derden en in rechte te vertegenwoordigen, of om deel te nemen aan het bestuur van, het toezicht op of de controle op de vennootschap, als bedoeld in artikel 14 sub d Richtlijn 2017/1132, en (i) informatie over bijkantoren die de vennootschap in een andere lidstaat heeft geopend, met inbegrip van de naam, het registratienummer, de EUID en de lidstaat waar het bijkantoor is geregistreerd. De verplichting deze gegevens kosteloos te verstrekken zal uiteraard gevolgen hebben voor het verdienmodel van de Kamer van Koophandel in Nederland. ${ }^{66}$

De verplichting kosteloos de gegevens onder (h) te verstrekken roept enkele vragen op. ${ }^{67}$ Allereerst vindt er een verruiming plaats van gegevens die openbaar moeten worden

59. Zie art. 16 lid 3 Voorstel en Voorstel, p. 15. Onder huidig recht kunnen lidstaten besluiten de bekendmaking in het nationale publicatieblad te vervangen door een ander, even doeltreffend instrument, dat ten minste het gebruik van een systeem omvat dat in chronologische volgorde via een centraal elektronisch platform toegang tot de openbaar gemaakte informatie biedt. Zie art. 16 lid 5 Richtlijn 2017/1132. Zie voor Nederland art. 24 Hregw 2007 en Schutte-Veenstra 2013, p. 122.

60. Art. 16 lid 5 Voorstel. Hiervoor geldt een termijn van vijf (i.p.v. de algemene termijn van twee) jaar na inwerkingtreding van de richtlijn, zie art. 2 Voorstel. Zie voor het opvragen van een kopie, art. 16 bis Voorstel.

61. Zie art. 19

62. Voorstel, p. 15.

63. Het gaat om: naam en rechtsvorm, statutaire zetel en registratienummer. Zie art. 19 lid 2 Richtlijn 2017/1132.

64. '(zoals: bedrijfsactiviteiten gestaakt, doorgehaald in het register, geliquideerd, ontbonden, economisch actief of inactief, zoals omschreven in het nationale recht, mits deze informatie beschikbaar is in de nationale registers)'.

65. Voor sub g geldt een termijn van vijf jaar na inwerkingtreding van de richtlijn, zie art. 2 Voorstel.

66. In 2014 is bij de $\mathrm{KvK}$ een vergaande reorganisatie doorgevoerd, met als resultaat onder meer één Kamer van Koophandel. Zie Asser/Maeijer \& Kroeze 2-1*2015/267.

67. Zie ook reactie GCV, nr. 1.2, die tevens aandacht voor de AVG vraagt. 


\section{Maandblad}

Ondernemingsrecht

gemaakt, en bovendien dat dit kosteloos moet gebeuren. Onder huidig recht moet openbaar worden gemaakt de identiteit van de personen die, als orgaan waarin de wet voorziet of als leden van een dergelijk orgaan, de bevoegdheid hebben de vennootschap ten opzichte van derden te verbinden en haar in rechte te vertegenwoordigen. ${ }^{68}$ Dat is iets anders dan de personen die door de vennootschap zijn gemachtigd om haar te vertegenwoordigen, zoals in (h) vermeld. Omdat deze gemachtigden niet onder het strenge vertegenwoordigingsregime van art. 9 Richtlijn 2017/1132 - waarbij beperkingen in beginsel niet aan derden kunnen worden tegengeworpen - vallen, ${ }^{69}$ ligt deze verplichte verruiming zonder kennis van de inhoud van de volmacht niet voor de hand. ${ }^{70}$ Voorts geldt dat de gegevens over bestuurders en toezichthouders onder $(\mathrm{h})$ overeenkomen met de gegevens die, volgens hetzelfde artikel, maximaal tegen kostprijs moeten worden verstrekt. Of bestuurders alleen of gezamenlijk vertegenwoordigingsbevoegd zijn, hoeft volgens het voorstel niet kosteloos te worden verstrekt, terwijl dit - door de mogelijkheid de tweehandtekeningenclausule wel aan derden tegen te werpen - in de praktijk uiterst relevant is.

\section{Gediskwalificeerde bestuurders}

Het richtlijnvoorstel kent een regeling inzake gediskwalificeerde bestuurders. Zij voorziet in de mogelijkheid voor het register waar de vennootschap moet worden geregistreerd de registers van andere lidstaten te laten bevestigen of de persoon die als bestuurder van de vennootschap moet worden benoemd, op dat moment gediskwalificeerd is om als bestuurder in die andere lidstaten op te treden. ${ }^{71}$ Lidstaten worden verplicht ervoor te zorgen dat deze informatie, inclusief de periode waarin de diskwalificatie van kracht is, door hun registers kan worden verstrekt. De lidstaten kunnen tevens de gronden voor de diskwalificatie meedelen. Als kernbepaling geldt dat de lidstaten de benoeming van een persoon als bestuurder van een vennootschap kunnen weigeren, indien die persoon op dat moment gediskwalificeerd is om als bestuurder op te treden in een andere lidstaat. Omdat er in de EU geen geharmoniseerde regels gelden over dit onderwerp en omdat niet alle lidstaten

68. Art. 14 sub d Richtlijn 2017/1132. Uit de openbaarmaking moet tevens blijken of de personen die de bevoegdheid hebben de vennootschap te verbinden, dit alleen of slechts gezamenlijk kunnen doen.

69. Zie daarvoor E.E.G. Gepken-Jager, Vertegenwoordiging bij NV en BV. Een rechtsvergelijkend onderzoek naar de uitvoering van artikel 9 eerste EG-richtlijn inzake het vennootschapsrecht (diss. Groningen), Deventer: Kluwer 2000

70. In Nederland geldt voor kapitaalvennootschappen wel de verplichting de persoonlijke gegevens in het handelsregister op te nemen van anderen dan de bestuurders aan wie de statuten de bevoegdheid tot vertegenwoordiging toekennen en de inhoud van de bevoegdheid. Zie art. 22 lid 1 sub b Hregb 2008.

71. Zie art. 13 nonies Voorstel. Voorwaarde is dat de lidstaten gebruik hebben gemaakt van art. 13 septies lid 4 sub d Voorstel. Onder bestuurder moet ook toezichthouder worden verstaan, art. 13 nonies lid 1 Voorstel jo. art. 14 sub d Richtlijn 2017/1132. een regeling kennen, ${ }^{72}$ ligt opneming van de regeling in het voorstel niet voor de hand en roept zij diverse vragen op.

In de toelichting bij het voorstel is te lezen:

'In het licht van bepaalde problemen waarop een aantal belanghebbenden in het kader van de openbare raadpleging heeft gewezen, zijn binnen de werkingssfeer van het voorstel echter waarborgen tegen fraude en misbruik opgenomen, zoals de verplichte identificatiecontrole, regels inzake gediskwalificeerde bestuurders (...). ${ }^{73}$

De Commissie beschouwt het met andere woorden als fraude of misbruik wanneer een gediskwalificeerde bestuurder in een andere lidstaat als bestuurder benoemd wil worden. Maar goed denkbaar is dat de lidstaat die de benoeming volgens het richtlijnvoorstel mag weigeren zelf geen regeling voor gediskwalificeerde bestuurders heeft, of een regeling die niet (helemaal) overeenkomt. ${ }^{74}$ In dat geval is bij het willen worden van bestuurder in de andere lidstaat juridisch gezien nog geen sprake van fraude of misbruik. Zonder een materiële geharmoniseerde regeling in de EU is een weigering louter op grond van een buitenlandse diskwalificatie dan ook problematisch.

De toelichting bij het voorstel suggereert dat het register zal weten bij welke lidstaat de navraag moet worden gedaan, vermoedelijk vanuit de gedachte dat het zal gaan om de lidstaat van de nationaliteit van de bestuurder. ${ }^{75}$ Door het recht op vrije vestiging van personen zal het register, om er zeker van te zijn dat geen sprake is van een diskwalificatie, de registers van alle andere lidstaten in de EU moeten raadplegen. Andersom zal in de praktijk vermoedelijk eerder sprake zijn van een gediskwalificeerde bestuurder die de diskwalificatie wil omzeilen door in dezelfde lidstaat bestuurder te worden van een buitenlandse vennootschap (in Nederland: een formeel buitenlandse vennootschap). Om die route tegen te gaan is de voorgestelde regeling in de richtlijn niet nodig, nu het register van de diskwalificatie op de hoogte zou moeten zijn. ${ }^{76}$ Ook is mogelijk een buitenlandse vennootschap, bestuurd door de gediskwalificeerde bestuurder, als bestuurder van de Neder-

72. Zie voor een (voorzichtige) aanbeveling voor een geharmoniseerde EUregeling inzake gekwalificeerde bestuurders, Report of the High Level Group of company law experts on a modern regulatory framework for company law in Europe (2002), Recommendation III.14 en p. 69 e.v. Zie voor Nederland de Wet civielrechtelijk bestuursverbod en art. 106a t/m $106 \mathrm{e}$ Fw.

73. Voorstel, p. 5.

74. Vgl. reactie GCV, nr. 2.7. Zo ziet de Nederlandse regeling niet op commissarissen en niet op niet-uitvoerende bestuurders (en wel op feitelijk beleidsbepaler), terwijl zij in het voorstel gelijk worden gesteld met bestuurders (art. 13 nonies lid 1 Voorstel jo. art. 14 sub d Richtlijn 2017/1132).

75. Voorstel, p. 14-15, waar als voorbeeld wordt gegeven dat lidstaat A navraag doet bij lidstaat $\mathrm{B}$.

76. Zo mag de notaris in Nederland op grond van de Wet civielrechtelijk bestuursverbod niet meewerken aan oprichting en inschrijving in het handelsregister van een BV of NV waarin een bestuurder wordt benoemd die een bestuursverbod opgelegd heeft gekregen, aldus reactie KNB, p. 8. 


\section{Maandblad}

landse vennootschap te laten optreden. ${ }^{77}$ Zolang deze andere lidstaat het Nederlandse bestuursverbod niet overneemt, kan de in Nederland gediskwalificeerde bestuurder worden benoemd als bestuurder in de buitenlandse vennootschap.

\section{Slot}

Gezien de praktische mogelijkheden die digitale middelen met zich brengen, is het toe te juichen dat de Europese Commissie het initiatief heeft genomen tot verdergaande geharmoniseerde regels inzake het gebruik van digitale instrumenten en processen. En door de ruime uitleg van het recht op vrije vestiging door het Hof van Justitie van de $\mathrm{EU}^{78}$ en de toenemende mogelijkheden voor grensoverschrijdende mobiliteit neemt de behoefte aan 'buitenlandse' oprichtingen en de kennis over buitenlands vennootschapsrecht toe.

In de reacties op de consultatie in Nederland, die vooral uit de notariële hoek komen, wordt de maatschappelijke rol van de notaris benadrukt en worden zorgen geuit over toenemende fraude door volledige online oprichting. Tevens zijn er vragen en zorgen over de toekomstige rol van de notaris. Mijns inziens zijn de zorgen over de notariële tussenkomst op basis van het richtlijnvoorstel onterecht en raakt het voorstel alleen de huidige praktijk van verplichte fysieke aanwezigheid. Vragen en onduidelijkheden zijn er wel op andere onderdelen, zoals over de facultatieve elementen bij de online registratie van vennootschappen, over de kosteloos te verstrekken informatie, over de regeling van gediskwalificeerde bestuurders en over vertalingen van documenten die vennootschappen voor buitenlandse registers mogen gebruiken. In plaats van de verplichting modellen beschikbaar te stellen in een officiële taal van de Unie die zo veel mogelijk grensoverschrijdende gebruikers in grote lijnen begrijpen, is aan te bevelen het Engels als gemeenschappelijke taal aan te wijzen, naast de eigen taal van de lidstaat.

Indien het voorstel wordt aangenomen, zal vijf jaar na de inwerkingtreding van de richtlijn worden bezien of volledige online registratie van NV's en een geharmoniseerd model voor oprichting van BV's noodzakelijk en haalbaar zijn.

77. Zie M. Zilinsky, Civielrechtelijk bestuursverbod en bestuurder van een buitenlandse rechtspersoon, WPNR 2016/7097.

78. Zo kunnen ondernemers door de rechtspraak van het Hof buitenlandse vennootschapstypen in eigen land gebruiken, voor zover het land van oprichting de incorporatieleer toepast. Zie voor een recente bespreking van deze rechtspraak M.A. Verbrugh, Grensoverschrijdende zetelverplaatsing op grond van de vrijheid van vestiging: het laatste stukje van de puzzel in het Polbud-arrest?, A\&O 2018, afl. 1, p. 14-22. 